\title{
Populasi dan Distribusi Keong Mas (Pomacea canaliculata L.) sebagai Sumber Pakan Ternak pada Ekosistem Persawahan di Kota Bengkulu
}

\author{
Population and Distribution of Golden Snail (Pomacea canaliculata L.) as Feed Resources in \\ Paddy Field Ecosystem in Bengkulu City
}

K. Saputra, Sutriyono, dan B. Brata

Jurusan Peternakan, Fakultas Pertanian, Universitas Bengkulu

Jl. WR Supratman, Kandang Limun, Bengkulu, 38371A

Email: kurniawansaputra26@gmail.com

\begin{abstract}
This study aims to determine the presence of a golden snail (Pomacea canaliculata L.) in terms of population and its distribution in nature. This research has been conducted in September-October 2017 located in Bengkulu City. This research used survey method with sampling technique in systematic sampling with quadratic frame measuring $5 \times 5$ meter as many as 17 plots based on sequence from member of population which amounted to 49 plots at each observation station. Environmental condition of observation station has humidity ranged from $71 \%-83.4 \%$, environmental temperature of $28.4-28.8^{\circ} \mathrm{C}, \mathrm{pH}$ of wetland waters $5.9-6.5$, and temperature of rice field of $25.3-$ $28.8^{\circ} \mathrm{C}$. The density of mas snail population ranged from $0-5.78$ individuals $/ \mathrm{m} 2$ with the value of Morisita Index at the observation station of Rawa Makmur, Semarang, and Bukit Besar villages ranged from 0.002 to 0.024 which showed a regular dispersion pattern (Id $<1$ ), whereas observation station in Kelurahan Kandang Limun did not get the index value of morisita because no golden snail samples were found during the research. The frequency of finding the golden snail on the three observation stations of $100 \%$, except in the Village of Kandang Limun which has a frequency of $0 \%$. The abundance of snail mas on the three stations is quite rare with the abundance of 3.52 tail $/ \mathrm{m} 2-5.78$ tail $/ \mathrm{m} 2$, while the observation station Kandang Limun Village has an abundance of 0 tail $/ \mathrm{m} 2$ or very rare. From this research, it can be concluded that golden snail population in paddy field ecosystem in Bengkulu City has regular distribution pattern $(\mathrm{Id}<1)$ with rare abundance up to very rare.
\end{abstract}

Key words: population, distribution, golden snail, ecosystem

\begin{abstract}
ABSTRAK
Penelitian ini bertujuan untuk mengetahui keberadaan keong mas (Pomacea canaliculata L.) ditinjau dari sisi populasi dan penyebarannya di alam. Penelitian ini telah dilaksakan pada bulan September-Oktober tahun 2017 bertempat di Kota Bengkulu. Penelitian ini menggunakan metode survey dengan teknik pengambilan sampel secara sistematis sampling dengan kerangka kuadrat berukuran $5 \times 5$ meter sebanyak 17 plot berdasarkan urutan dari anggota populasi yang jumlahnya sebanyak 49 plot pada masing-masing stasiun pengamatan. Kondisi lingkungan stasiun pengamatan memiliki kelembaban berkisar antara $71 \%-83,4 \%$, suhu lingkungan $28,4-28,8^{\circ} \mathrm{C}$, pH perairan sawah 5,9-6,5, dan suhu perairan sawah $25,3-28,8^{\circ} \mathrm{C}$. Kepadatan populasi keong mas berkisar antara $0-5,78$ individu $/ \mathrm{m}^{2}$ dengan nilai Indeks Morisita pada stasiun pengamatan Kelurahan Rawa Makmur, Kelurahan Semarang, dan Kelurahan Bukit Besar berkisar antara 0,002 - 0,024 yang menunjukkan pola penyebaran teratur (Id $<1)$, sedangkan pada stasiun pengamatan Kelurahan Kandang Limun tidak diperoleh nilai indeks morisita karena tidak ditemukan sampel keong mas saat penelitian berlangsung. Frekuensi ditemukannya keong mas pada ketiga stasiun pengamatan sebesar $100 \%$, kecuali pada Kelurahan Kandang Limun yang memiliki frekuensi $0 \%$. Kelimpahan keong mas pada ketiga stasiun pegamatan cukup jarang dengan kelimpahan 3,52 ekor $/ \mathrm{m}^{2}-5,78 \mathrm{ekor} / \mathrm{m}^{2}$, sedangkan pada stasiun pengamatan Kelurahan Kandang Limun memiliki kelimpahan 0 ekor $/ \mathrm{m}^{2}$ atau sangat jarang. Dari penelitian ini dapat disimpulkan bahwa populasi keong mas pada ekosistem persawahan di Kota Bengkulu memiliki pola distribusi teratur $(\mathrm{Id}<1)$ dengan kelimpahan jarang hingga sangat jarang.
\end{abstract}

Kata kunci: populasi, distribusi, keong mas, ekosistem

\section{PENDAHULUAN}

Keong mas atau keong murbei

(Pomacea canaliculata L.) dari suku
Ampullariidae merupakan keong air tawar pendatang dari Amerika Selatan yang masuk ke Indonesia sekitar awal 1980-an dan menjadi hama tanaman padi yang serius di Indonesia 
juga di Asia Tenggara. Ribuan hektar semai padi, atau tanaman padi berumur muda rusak dihamai oleh keong mas yang selama ini diidentifikasi sebagai jenis Pomacea canaliculata. Keong mas merupakan moluska yang ditetapkan sebagai organisme pengganggu tanaman (OPT) atau hama utama pada tanaman padi (Oryza sativa) di sawah. Organisme ini berpotensi sebagai hama utama karena sawah merupakan habitat yang cocok bagi perkembangannya, sehingga keong mas dapat berkembang biak sangat cepat dan mampu merusak tanaman padi dalam waktu yang cepat (Hendarsih dan Kurniawati, 2009).

Penyebaran keong mas di Kota Bengkulu cukup luas jangkauannya, dan hampir di semua area persawahan Kota Bengkulu dapat ditemui ratusan hingga ribuan keong mas. Salah satu kasus penyebaran keong mas yaitu yang terjadi di Tanjung Agung Kota Bengkulu. Pasca turun tanam padi dan hingga berumur 2 minggu, petani di Tanjung Agung, Kota Bengkulu, diresahkan dengan keberadaan hama keong mas yang berkembang biak lebih cepat di musim penghujan. Diperkirakan setiap petak sawah, ribuan keong mas bertebaran, baik anak keong yang baru menetas maupun keong mas dewasa (Portal Berita Info Publik, 2016).

Pemberantasan keong mas hingga saat ini masih terus dilakukan oleh para petani khususnya di Kota Bengkulu. Hal tersebut membuat keberadaan dari keong mas menjadi terancam seiring dengan maraknya upaya pemberantasan yang dilakukan baik itu menggunakan pestisida kimia ataupun menggunakan cara alami. Dengan berkurangnya populasi keong mas, potensi yang seharusnya dapat dimanfaatkan petani dan masyarakat menjadi berkurang bahkan berangsur-angsur menghilang.

Pada saat ini penyediaan bahan baku pakan lokal menjadi demikian penting dan sifatnya mendesak, terutama bila dikaitkan dengan harga pakan unggas yang terus mengalami kenaikan dari waktu ke waktu. Hal ini mudah dimaklumi karena bahan baku dalam pakan umumnya adalah impor, sehingga sudah saatnya sekarang melakukan upaya alternatif berupa penyediaan bahan baku lokal (Pagala, 2010).

Salah satu bahan baku lokal yang banyak terdapat di Indonesia adalah keong mas (Pomacea canaliculata L.). Menurut Halimah dan Ismail (1989), daging keong mas diperkirakan mengandung protein $11,64 \%$ dan lemak 0,54\% dari bobot basah, dan setiap 100 gram dagingnya mengandung sedikitnya 12 gram protein, 64 kkal energi, 2 gram karbohidrat dan sejumlah mineral seperti phosphor, besi, kalsium, magnesium dan iodium serta mengandung vitamin $\mathrm{C}$ (Sihombing, 1999). Sementara itu Martawidjaya et al. (2008) menjelaskan bahwa salah satu sumber bahan baku yang dapat digunakan sebagai pakan itik petelur adalah tepung keong mas karena mengandung nutrisi cukup tinggi seperti protein sekitar 54\%, lemak $4-5 \%$, karbohidrat $30 \%$ serta sejumlah mineral penting lainnya seperti kalsium dan fosfor. Penggunaan tepung keong mas pada level $10 \%$ ransum dapat meningkatkan produksi telur pada varietas itik Tegal (Pagala, 2010). Selain itu penambahan tepung keong mas (Pomacea canaliculata L.) pada pakan ayam petelur dapat meningkatkan kualitas pakan dan kandungan Omega-3 pada telur ayam ras petelur (Nurmufidah, 2015). Dari 
berbagai hasil penelitian menunjukkan bahwa pemberian keong mas pada itik dan ayam mampu meningkatkan produksi telur dan bobot badan (Susanto, 1993). Potensi yang dimiliki oleh keong mas hingga saat ini masih sangat sedikit termanfaatkan. Hal tersebut dapat dikarenakan kurangnya pengetahuan dan pengalaman petani dalam memanfaatkan potensi keong mas sebagai sumber protein hewani, baik untuk pakan ternak ataupun sebagai sumber protein hewani alternatif untuk manusia.

Informasi mengenai pola distribusi keong mas masih sangat kurang, khususnya di Kota Bengkulu. Studi populasi dan pola distribusi mengenai keong mas di Kota Bengkulu hingga saat ini belum ada yang melakukannya. Oleh karena itu, penelitian ini diharapkan dapat memperoleh informasi mengenai pola distribusi keong mas khususnya yang hidup pada ekosistem persawahan di Kota Bengkulu, agar kedepannya dapat digunakan sebagai bahan pertimbangan dalam kegiatan berburu keong mas di alam untuk dijadikan sumber pakan ternak. Marwoto et al. (2011) mengatakan bahwa mempelajari keanekaragaman jenis keong air tawar akan berguna untuk mendukung kegiatan lain dalam pengelolaan lingkungan, seperti memprediksi tingkat pencemaran suatu perairan, menjaga siklus alami dan memberantas penyakit yang disebabkan oleh cacing parasit.

Tujuan penelitian untuk mengetahui keberadaan keong mas (Pomacea canaliculata L.) ditinjau dari sisi populasi dan penyebarannya di alam. Dapat dijadikan pedoman dalam berburu keong mas (Pomacea canaliculata L.) sebagai sumber pakan ternak di Kota Bengkulu.

\section{MATERI DAN METODE}

Penelitian ini dilaksanakan pada bulan September - Oktober 2017 di empat lokasi persawahan yang berbeda dalam Kota Bengkulu. Lokasi penelitian terdiri dari Kelurahan Rawa Makmur, Kelurahan Semarang (area persawahan Dinas Pangan dan Pertanian Kota Bengkulu), Kelurahan Dusun Besar, dan terakhir di area persawahan dalam lingkungan Universitas Bengkulu Kelurahan Kandang Limun Kota Bengkulu. Penelitian dilaksanakan pada pagi hari pukul 06.00 09.00 WIB.

Alat dan bahan yang digunakan terdiri dari meteran, tali rafiah, tonggak kayu, jam, kamera, kantong plastik yang telah diberi nomor plot, termometer, higrometer, $\mathrm{pH}$ meter, air bersih dan alat tulis.

Tahapan penelitian meliputi penentuan lokasi penelitian, pembuatan kuadrat (plot), pengamatan suhu air sawah, $\mathrm{pH}$ air sawah, suhu lingkungan, dan kelembaban lingkungan, serta pengambilan sampel keong mas (Pomacea canaliculata L.) pada masingmasing plot yang telah ditentukan.

Lokasi ditentukan secara purposive sampling yaitu metode penetapan sampel/lokasi dengan memilih beberapa sampel/lokasi tertentu yang dinilai sesuai dengan tujuan atau masalah penelitian dalam suatu populasi (Nursalam, 2008).

\section{Pembuatan Kuadrat (Plot)}

Sebelum penelitian dilaksanakan, dilakukan pembuatan kuadrat (plot) menggunakan tonggak dan tali rafiah dengan 
masing-masing kuadrat berukuran $5 \mathrm{~m} \mathrm{x} 5 \mathrm{~m}$ sebanyak 49 plot. Taknik pengambilan sampel menggunakan teknik sistematis sampling yaitu teknik pengambilan sampel berdasarkan urutan dari anggota populasi yang telah diberi nomor urut (Sugiyono, 2015). Dalam penelitian ini menggunakan plot yang jumlahnya 49. Plot yang terpilih untuk diambil sampelnya dimulai dari plot nomor 1 dan dilanjutkan dengan plot yang memiliki kelipatan bilangan 3. Jadi plot yang terpilih untuk diambil sampelnya yaitu plot nomor 1, 3, 6, 9, 12, 15, 18, 21, 24, 27, 30, $33,36,39,42,45$, dan 48 sehingga total plot terpilih berjumlah 17 plot. Plot yang terpilih dapat dilihat pada gambar 1 di bawah ini.

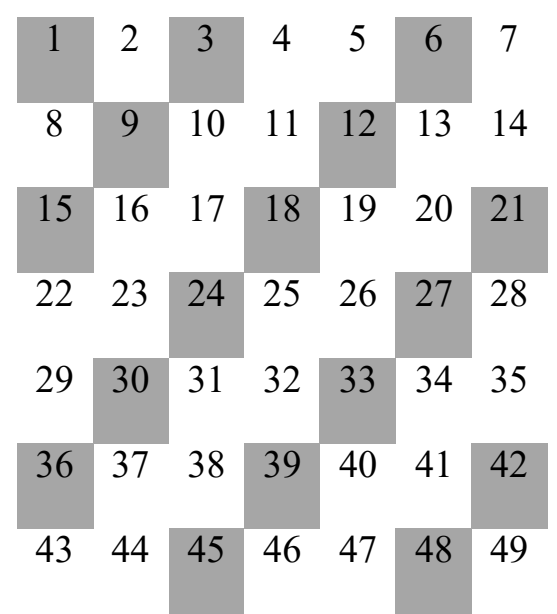

Gambar 1. Gambaran plot penelitian dengan sistematis sampling

\section{Pengamatan Kondisi Lingkungan Penelitian}

Pengamatan kondisi lingkungan penelitian dilakukan untuk mengetahui pengaruh lingkungan terhadap pola distribusi keong mas (Pomacea canaliculata L.) pada area persawahan yang diteliti. Kondisi lingkungan yang diamati terdiri dari pengamatan $\mathrm{pH}$ air sawah, suhu air sawah, suhu lingkungan dan kelembaban lingkungan, serta mengamati faktor-faktor lain yang memungkinkan untuk dapat mempengaruhi pola distribusi keong mas seperti ketersediaan makanan bagi keong mas, adanya kemungkinan predator, dan usaha pemberantasan hama keong mas oleh petani.

\section{Pengambilan Sampel Keong Mas}

Pengambilan sampel keong mas dilakukan bertahap mulai dari plot 1, 3, 6, 9 hingga plot 48. Ukuran keong mas yang diambil sebagai sampel tidak berdasarkan ukuran, artinya keong mas yang berukuran kecil hingga berukuran besar semuanya diambil sebagai sampel. Jumlah keong mas diperoleh dari hasil pengambilan sampel dan dihitung jumlahnya pada tiap-tiap plot terpilih (baik yang di permukaan perairan, di dalam perairan maupun yang menempel di atas tumbuhan air).

\section{Variabel yang diamati}

Variabel yang diamati pada penelitian ini meliputi kepadatan, pola distribusi, frekuensi dan kelimpahan keong mas pada ekosistem persawahan di Kota Bengkulu.

\section{Kepadatan}

Kepadatan keong mas (Pomacea canaliculata L.) pada setiap stasiun pengamatan dihitung dan dikonversikan dalam satuan individu $/ \mathrm{m}^{2}$ menggunakan rumus Brower and Zar (1990) :

$$
D=\frac{\mathrm{N}}{\mathrm{A}}
$$

dimana $\mathrm{D}=$ jumlah individu per satuan luas (individu $/ \mathrm{m}^{2}$ ), $\mathrm{N}=$ jumlah total individu dalam satuan luas, dan $\mathrm{A}=$ luas plot kuadrat $\left(\right.$ meter $\left.^{2}\right)$.

\section{Pola Distribusi}

Pola distribusi yaitu mengambil dan menghitung semua individu yang terdapat di 
tiap-tiap plot, selanjutnya dianalisis dengan menggunakan rumus Indeks Morisita (Elfazuri, 1993):

$$
\mathrm{Id}=\frac{\sum \mathrm{ni}(\mathrm{ni}-1) \mathrm{N}}{\mathrm{n}(\mathrm{ni}-1)}
$$

dimana Id = Indeks Morisita, ni $=$ Jumlah individu tiap plot, dan $\mathrm{N}=$ Jumlah total individu semua plot, dengan ketentuan sebagai berikut $\mathrm{Id}=1$ pola distribusi adalah acak, Id > 1 pola distribusi adalah mengelompok, dan Id $<1$ pola distribusi adalah teratur.

\section{Frekuensi}

Frekuensi adalah proporsi jumlah plot ditemukannya suatu spesies dari semua plot yang diamati. Frekuensi kehadiran dihitung dengan rumus seperti berikut (Suin, 1999) :

$$
\mathrm{F}_{\mathrm{i}}=\frac{j i}{k} \times 100 \%
$$

dimana $F_{i}=$ Frekuensi jenis ke $i, j_{i}=$ Jumlah plot dimana spesies ke i terdapat, dan $\mathrm{k}=$ Jumlah semua plot yang diamati.

\section{Kelimpahan}

Analisis kelimpahan keong mas berdasarkan jumlah individu per satuan luas dihitung dengan menggunakan rumus (Bakus, 1990):

$$
\mathrm{A}=\frac{\mathrm{X} i}{\mathrm{~N} i}
$$

dimana: $A=$ Kelimpahan populasi (ind $\left./ \mathrm{m}^{2}\right), X_{i}$ $=$ Jumlah individu, dan $\mathrm{N}_{\mathrm{i}}=\operatorname{Luas}\left(\mathrm{m}^{2}\right)$.

\section{Analisis Data}

Data yang telah diperoleh kemudian disajikan dalam bentuk tabel dan grafik serta dibahas secara deskriptif.

\section{HASIL DAN PEMBAHASAN}

\section{Keadaan Umum Lokasi Penelitian}

Kota Bengkulu merupakan ibu kota Provinsi Bengkulu yang memilki luas 151.7 $\mathrm{km}^{2}$. Kota Bengkulu terletak di posisi barat Pulau Sumatera berada diantara $30,45^{\circ}-30,59^{\circ}$ Lintang Selatan serta $102,02^{\circ}$ Bujur Timur. Kota Bengkulu memilki relief permukan tanah yang bergelombang, terdiri dari daratan pantai dan daerah bukit-bukit serta di beberapa tempat terdapat cekungan alur sungai kecil (Permendagri No. 66 tahun 2011). Dalam penelitian ini, lokasi yang dipilih sebagai stasiun pengamatan terdiri dari Kelurahan Rawa Makmur, Kelurahan Semarang, Kelurahan Dusun Besar, dan Kelurahan Kandang Limun.

Tabel 1. Keadaan umum lokasi penelitian

\begin{tabular}{ccccc}
\hline Stasiun Pengamatan & $\begin{array}{c}\text { Kelembaban } \\
\text { Lingkungan }(\%)\end{array}$ & $\begin{array}{c}\text { Suhu } \\
\text { Lingkungan }\left({ }^{\circ} \mathrm{C}\right)\end{array}$ & $\begin{array}{c}\text { pH Perairan } \\
\text { Sawah }\end{array}$ & $\begin{array}{c}\text { Suhu Perairan } \\
\text { Sawah }\left({ }^{\circ} \mathrm{C}\right)\end{array}$ \\
\hline Rawa Makmur & 71 & 28,5 & 6,5 & 25,3 \\
Semarang & 76 & 28,8 & 6,4 & 28,8 \\
Dusun Besar & 83,4 & 28,7 & 5,9 & 27,5 \\
Kandang Limun & 83 & 28,4 & 6,2 & 27,7 \\
\hline
\end{tabular}

Berdasarkan Tabel 1 di atas, dapat diketahui kelembaban lokasi penelitian berkisar antara $71 \%$ hingga $83,4 \%$, suhu lingkungan $28,4-28,8{ }^{\circ} \mathrm{C}, \mathrm{pH}$ perairan sawah 5,9-6,5, dan suhu perairan sawah $25,3-28,8^{\circ} \mathrm{C}$. Suhu perairan yang berhasil diamati dalam penelitian ini yaitu berkisar antara 25,3-28,8 ${ }^{\circ} \mathrm{C}$. Suhu perairan tersebut termasuk ideal untuk perkembangbiakan keong mas di alam. Hal tersebut didukung oleh pendapat Sulistiono (2007) yang menyatakan bahwa keong mas toleransi terhadap suhu antara 18- 
$28{ }^{\circ} \mathrm{C}$. Hal yang sama juga disampaikan oleh Susanto (1993) bahwa keong mas menyukai daerah yang lembab atau berair dengan perairan yang dangkal, dan air yang mengalir pelan secara terus menerus, dengan kondisi lingkungan yang jernih serta suhu air yang berkisar antara $10^{\circ} \mathrm{C}-35^{\circ} \mathrm{C}$. Selain itu $\mathrm{pH}$ perairan yang diamati juga masih tergolong ideal untuk lingkungan tempat hidup keong mas karena masih berada pada kisaran 5,9-6,5. Menurut Sulistiono (2007), keong mas dapat hidup pada air yang memiliki pH 5-8.

\section{Kepadatan Keong Mas}

Kepadatan keong mas pada empat stasiun pengamatan di Kota Bengkulu disajikan pada Tabel 2.

Tabel 2. Kepadatan keong mas

\begin{tabular}{ccccc}
\hline \multirow{2}{*}{ Nomor Plot } & $\begin{array}{c}\text { Rawa } \\
\text { Makmur }\end{array}$ & $\begin{array}{c}\text { Stasiun Pengamatan } \\
\text { Semarang }\end{array}$ & $\begin{array}{c}\text { Dusun Besar } \\
\text { Kandang } \\
\text { Limun }\end{array}$ \\
\hline 1 & 42 & 13 & 12 & 0 \\
3 & 33 & 18 & 7 & 0 \\
6 & 16 & 14 & 16 & 0 \\
9 & 27 & 25 & 14 & 0 \\
12 & 34 & 12 & 24 & 0 \\
15 & 19 & 16 & 16 & 0 \\
18 & 22 & 19 & 24 & 0 \\
21 & 38 & 14 & 21 & 0 \\
24 & 21 & 11 & 25 & 0 \\
27 & 13 & 23 & 27 & 0 \\
30 & 36 & 27 & 16 & 0 \\
33 & 39 & 13 & 22 & 0 \\
36 & 27 & 14 & 13 & 0 \\
39 & 20 & 17 & 28 & 0 \\
42 & 47 & 22 & 21 & 0 \\
45 & 34 & 29 & 14 & 0 \\
48 & 24 & 13 & 19 & 0 \\
\hline Jumlah $\left(\right.$ per $\left.5 \mathrm{~m}^{2}\right)$ & 492 & 300 & 319 & 0 \\
\hline Rata-rata $\left(\right.$ per $\left.5 \mathrm{~m}^{2}\right)$ & 28,94 & 17,64 & 18,76 & 3,75 \\
\hline Jumlah ind $/ \mathrm{m}^{2}$ & 5,78 & 3,52 & & \\
\hline
\end{tabular}

Berdasarkan tabel di atas, dapat dilihat bahwa kepadatan rata-rata tertinggi Pomacea canaliculata terdapat di stasiun pengamatan Kelurahan Rawa Makmur dengan kepadatan 5,78 individu $/ \mathrm{m}^{2}$, kemudian diikuti oleh stasiun pengamatan Kelurahan Dusun Besar dengan kepadatan 3,75 individu $/ \mathrm{m}^{2}$, dan stasiun pengamatan Kelurahan Semarang dengan kepadatan 3,52 individu $/ \mathrm{m}^{2}$, sedangkan untuk stasiun pengamatan di Kelurahan Kandang Limun tidak ditemukan adanya keong mas. Tingginya kepadatan keong mas di stasiun pengamatan Kelurahan Rawa Makmur mungkin disebabkan oleh adanya jenis produsen yang lebih bervariasi dibandingkan dengan stasiun pengamatan lainnya, disamping itu faktor abiotik seperti kecerahan air yang lebih tinggi dan substrat yang berlumpur akan lebih mendukung bagi kehidupan populasi keong mas di area persawahan Kelurahan Rawa Makmur ini. Pernyataan ini didukung oleh pendapat 
Nurhidayati (1993), yang menyatakan keong banyak tumbuhan air dan substrat yang mas lebih menyukai perairan yang jernih, berlumpur.

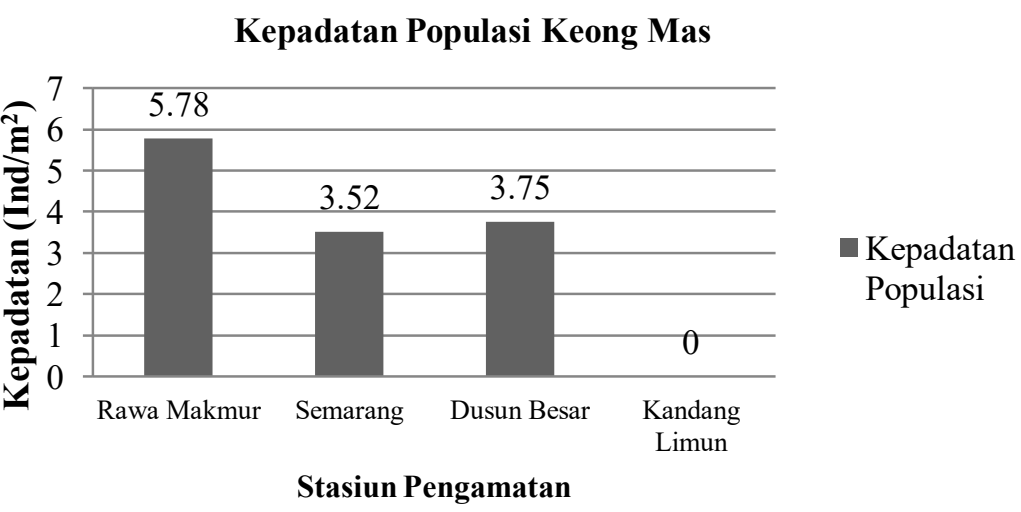

Gambar 2. Grafik Kepadatan Populasi Keong Mas

Keberadaan keong mas pada suatu wilayah dipengaruhi oleh berbagai faktor. Seperti halnya pada stasiun pengamatan Kelurahan Kandang Limun, tidak ditemukannya keong mas menunjukkan adanya faktor tertentu yang mempengaruhi keberadaannya di alam. Berdasarkan pengamatan yang telah dilakukan, faktor utama yang menjadi penyebab tidak ditemukannya keong mas pada area persawahan di Kelurahan Kandang Limun yaitu tidak adanya persediaan makanan karena area persawahan yang menjadi lokasi penelitian telah berubah menjadi rawa sehingga sumber makanan bagi keong mas tidak tersedia lagi. Selain itu, kondisi sawah yang seringkali mengering juga diduga menjadi penyebab tidak ditemukannya sampel keong mas pada stasiun pengamatan Kelurahan Kandang Limun.

Selain itu, faktor lain yang dapat mempengaruhi kepadatan populasi keong mas pada keempat stasiun pengamatan yaitu adanya upaya pemberantasan hama keong mas oleh petani. Masyarakat petani di Kota
Bengkulu sebagian besar memberantasnya dengan cara manual, yaitu dengan cara mengambilnya menggunakan tangan kemudian dimasukkan ke dalam kantong plastik atau karung, setelah itu keong mas dibiarkan di dalam kantong plastik atau karung sampai akhirnya membusuk. Hal tersebut dilakukan agar dapat mengurangi keberadaan hama keong mas yang dapat merugikan petani.

Menurut IRRI (2003), keong mas mampu bertahan hidup di dalam tanah sampai 6 bulan lamanya dan jika mendapat pengairan maka keong akan berkembang biak kembali. Hal ini juga kemungkinan besar menjadi penyebab tidak ditemukannya keong mas pada stasiun pengamatan Kelurahan Kandang Limun karena kondisi persawahan sudah berubah menjadi rawa karena telah lama tidak diolah dan juga kondisi lahan yang tidak stabil, hanya berair setelah turun hujan dan kembali kering setelah menerima panas matahari yang cukup lama. Hal tersebut menyebabkan keong mas sulit untuk bertahan hidup. 


\section{Pola Distribusi}

Pola distribusi keong mas pada empat stasiun pengamatan di Kota Bengkulu disajikan pada Tabel 3.

Tabel 3. Pola distribusi keong mas

\begin{tabular}{ccc}
$\begin{array}{c}\text { Stasiun } \\
\text { Pengamatan }\end{array}$ & $\begin{array}{c}\text { Nilai Indeks } \\
\text { Morisita } \\
\text { (Id) }\end{array}$ & $\begin{array}{c}\text { Pola } \\
\text { Penyebaran }\end{array}$ \\
\hline Rawa Makmur & 0,024 & Teratur \\
Semarang & 0,002 & Teratur \\
Dusun Besar & 0,005 & Teratur
\end{tabular}

Kandang Limun

Keterangan : Id $=1$ pola distribusi adalah acak, Id $>1$ pola distribusi adalah mengelompok, dan Id $<1$ pola distribusi adalah teratur (Elfazuri, 1993).

Berdasarkan Tabel 3 di atas, terlihat pola disribusi dari ketiga stasiun pengamatan memiliki pola penyebaran teratur, sedangkan untuk stasiun pengamatan Kelurahan Kandang Limun tidak diperoleh nilai indeks morisita karena tidak diperoleh sampel keong mas saat penelitian berlangsung. Nilai indeks morisita (Id) dari ketiga stasiun di atas yaitu $<1$, yang membedakan hanya nilai dari indeks morisita. Pada stasiun pengamatan Kelurahan Rawa Makmur nilai indek morisita yang diperoleh sebesar 0,024, selanjutnya pada stasiun pengamatan di Kelurahan Semarang nilai indeks morisita yang diperoleh sebesar 0,002 dan pada stasiun pengamatan di Kelurahan Dusun Besar nilai indeks morisita yang diperoleh sebesar 0,005 .

Pola distribusi teratur yang ditemukan pada tiga stasiun pengamatan kemungkinan disebabkan oleh banyaknya sumber makanan dan adanya daya dukung lingkungan yang baik untuk keong mas sehingga membuat ruang hidup antar individu terbagi secara merata. Menurut Michael (1984), penyebaran teratur atau seragam menggambarkan individuindividu terdapat pada tempat tertentu dalam komunitas. Penyebaran ini terjadi bila ada persaingan yang keras sehingga timbul kompetisi yang mendorong pembagian ruang hidup yang sama. Menurut Setiono (1999), pola penyebaran secara teratur jarang terjadi di alam dan umumnya terjadi hanya pada ekosistem yang dikelola. Penyebaran secara teratur menggambarkan jarak antara individu satu dan individu lainnya relatif sama seperti terlihat pada gambar 3 di bawah ini.

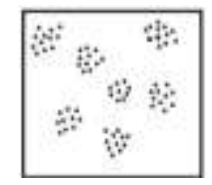

Berkelompok

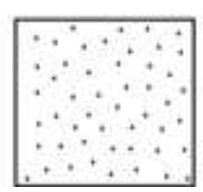

Teratur

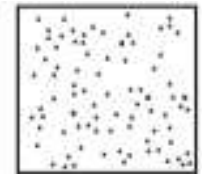

Acak
Gambar 3. Pola penyebaran individu dalam populasi

Noviyana (2012) menyatakan bahwa faktor habitat seperti fisik, kimia, dan musuh keong mas (seperti semut merah, burung, bebek dan manusia) serta ketersediaan sumber makanan bagi keong mas mempengaruhi keberadaan keong dan pola distribusinya di alam. Pola distribusi keong mas yang umum terdapat di alam yaitu pola distribusi yang bersifat mengelompok. Menurut Elfazuri (1993), mengelompoknya individu yang bergerak disebabkan oleh ketertarikan terhadap sumber makanan dan tempat perlindungan. Pola distribusi mengelompok dapat dilihat dari hasil penelitian yang telah dilakukan oleh Riyanto (2004) di Kecamatan Belitang OKU, Rozakiah (2014) di Bendungan Batang Samo Kabupaten Rokan Hulu, dan Widiastuti (2014) di Desa Jabungan Semarang yang memiliki nilai indeks morisita $>1$ sehingga memiliki pola distribusi mengelompok. 
Tabel 4. Frekuensi kehadiran keong mas

\begin{tabular}{ccccc}
\hline \multirow{2}{*}{ Nomor Plot } & \multicolumn{4}{c}{ Stasiun Pengamatan } \\
\cline { 2 - 5 } & Rawa Makmur & Semarang & Dusun Besar & $\begin{array}{c}\text { Kandang } \\
\text { Limun }\end{array}$ \\
\hline 1 & 42 & 13 & 12 & 0 \\
3 & 33 & 18 & 7 & 0 \\
6 & 16 & 14 & 16 & 0 \\
9 & 27 & 25 & 14 & 0 \\
12 & 34 & 12 & 24 & 0 \\
15 & 19 & 16 & 16 & 0 \\
18 & 22 & 19 & 24 & 0 \\
21 & 38 & 14 & 21 & 0 \\
24 & 21 & 11 & 25 & 0 \\
27 & 13 & 23 & 27 & 0 \\
30 & 36 & 27 & 16 & 0 \\
33 & 39 & 13 & 22 & 0 \\
36 & 27 & 14 & 13 & 0 \\
39 & 20 & 17 & 28 & 0 \\
42 & 47 & 22 & 21 & 0 \\
45 & 34 & 29 & 14 & 0 \\
48 & 24 & 13 & 19 & 0 \\
\hline Frekuensi (\%) & 100 & 100 & 100 & \\
\hline
\end{tabular}

Berdasarkan Tabel 4 di atas, frekuensi ditemukannya keong mas (Pomacea canaliculata L.) pada ketiga stasiun pengamatan yang terdiri dari stasiun pengamatan Kelurahan Rawa Makmur, Kelurahan Semarang, dan Kelurahan Dusun Besar memiliki frekuensi $100 \%$, sedangkan frekuensi kehadiran untuk stasiun pengamatan Kelurahan Kandang Limun 0\% karena sampel keong mas tidak dapat ditemukan pada saat penelitian. Tingginya frekuensi kehadiran keong mas pada tiga stasiun pengamatan menunjukkan besarnya potensi keong mas, baik potensi sebagai hama ataupun potensi sebagai sumber pakan ternak dan sumber makanan penghasil protein hewani alternatif bagi manusia.
Frekuensi kehadiran suatu jenis organisme di suatu habitat menunjukkan kesering-hadiran jenis tersebut di dalam suatu habitat. Dari frekuensi kehadiran itu dapat tergambar penyebaran jenis tersebut dalam suatu habitat. Bila frekuensi kehadirannya tinggi berarti jenis itu sering ditemukan di habitat tersebut. Dengan demikian, dari keempat stasiun pengamatan yang terpilih, ekosistem persawahan yang memiliki frekuensi kehadiran keong mas (Pomacea canaliculata L.) yang tinggi yaitu berada di stasiun pengamatan Kelurahan Rawa Makmur, Kelurahan Semarang, dan Kelurahan Dusun Besar yang memiliki frekuensi 100\%. Sedangkan untuk stasiun pengamatan rawa 
makmur 0\% karena tidak ditemukannya keong mas pada ekosistem sawah yang diamati.

Frekuesi kehadiran sering pula dinyatakan sebagai konstansi. Konstansi atau frekuensi kehadiran dapat dikelompokkan atas empat kelompok, yaitu jenis yang aksidental bila konstansinya $0-25 \%$, jenis assesori yang konstansinya $25-50 \%$, jenis yang konstan yang konstansinya $50-75 \%$, dan jenis yang absolut bila konstansinya lebih dari $75 \%$. Dengan demikian, frekuensi kehadiran dalam penelitian ini termasuk dalam kelompok absolut karena nilai konstansinya lebih dari $75 \%$ kecuali pada stasiun pengamatan kelurahan kandang limun yang memiliki frekuensi kehadiran $0 \%$ dan termasuk dalam kelompok aksidental.

\section{Kelimpahan}

Kelimpahan keong mas pada empat stasiun pengamatan di Kota Bengkulu disajikan pada Tabel 5 .

Tabel 5. Kelimpahan keong mas

\begin{tabular}{ccccc}
\hline \multirow{2}{*}{ Nomor Plot } & \multicolumn{3}{c}{ Stasiun Pengamatan } \\
\cline { 2 - 5 } & Rawa Makmur & Semarang & Dusun Besar & $\begin{array}{c}\text { Kandang } \\
\text { Limun }\end{array}$ \\
\hline 1 & 42 & 13 & 12 & 0 \\
3 & 33 & 18 & 7 & 0 \\
6 & 16 & 14 & 16 & 0 \\
9 & 27 & 25 & 14 & 0 \\
12 & 34 & 12 & 24 & 0 \\
15 & 19 & 16 & 16 & 0 \\
18 & 22 & 19 & 24 & 0 \\
21 & 38 & 14 & 21 & 0 \\
24 & 21 & 11 & 25 & 0 \\
27 & 13 & 23 & 27 & 0 \\
30 & 36 & 27 & 16 & 0 \\
33 & 39 & 13 & 22 & 0 \\
36 & 27 & 14 & 13 & 0 \\
39 & 20 & 17 & 28 & 0 \\
42 & 47 & 22 & 21 & 0 \\
45 & 34 & 29 & 14 & 0 \\
\hline 48 & 24 & 13 & 19 & 0 \\
\hline Jumlah $\left(5 \mathrm{~m}^{2}\right)$ & 492 & 300 & 319 & \\
\hline Kelimpahan & 5,78 & 3,52 & 3,75 & \\
ind/ $\mathrm{m}^{2}$ & & & & 0 \\
\hline
\end{tabular}

Berdasarkan Tabel 5 di atas, diperoleh data bahwa keong mas pada keempat stasiun pegamatan cukup berlimpah dengan kelimpahan 3,52 ekor $/ \mathrm{m}^{2}$ hingga 5,78 ekor $/ \mathrm{m}^{2}$, kecuali pada stasiun pengamatan Kelurahan Kandang Limun yang memiliki kelimpahan 0 ekor $/ \mathrm{m}^{2}$. Kelimpahan keong mas tertinggi terdapat pada stasiun pengamatan pertama tepatnya di Kelurahan Rawa Makmur dan terendah pada stasiun pengamatan Kelurahan Kandang Limun. Menurut Budiono (2006), kriteria dari kelimpahan yaitu jika $<1$ Individu $/ \mathrm{m}^{2}$ sangat jarang, 2-5 Individu $/ \mathrm{m}^{2}$ jarang, 6-10 Individu $/ \mathrm{m}^{2}$ sedang, 11-15 Individu $/ \mathrm{m}^{2}$ melimpah, dan $>15$ Individu $/ \mathrm{m}^{2}$ sangat melimpah. Berdasarkan pendapat 
Budiono (2006) tersebut, menunjukkan bahwa kriteria kelimpahan pada keempat stasiun pengamatan berkisar antara sangat jarang hingga jarang. Kriteria tersebut terdiri dari stasiun pengamatan Kelurahan Rawa Makmur, Semarang, dan Dusun Besar dengan kriteria kelimpahan jarang, sedangkan pada stasiun pengamatan Kelurahan Kandang Limun sangat jarang bahkan bisa dikatakan tidak ada karena tidak ditemukan satu ekorpun keong mas pada stasiun pengamatan tersebut.

Tingginya populasi keong mas pada stasiun pengamatan Kelurahan Rawa Makmur diperkirakan karena stasiun tersebut terletak dekat dengan muara sungai yang biasanya aliran sungai membawa partikel lumpur yang banyak mengandung bahan organik seperti detritus yang berasal dari sisa-sisa hancuran tumbuhan dan hewan sehingga membuat sumber makanan bagi keong mas berlimpah walaupun kondisi sawah tidak sedang musim tanam. Sedangkan pada stasiun pengamatan Kelurahan Semarang dan Kelurahan Dusun Besar sumber pengairan berasal dari irigasi danau dendam tak sudah, dan pada stasiun pengamatan Kelurahan Kandang Limun sumber pengairan sawah berasal dari air hujan karena sawah di sini berjenis sawah tadah hujan sehingga sumber makanan bagi keong mas tidak sebanyak yang berada di stasiun pengamatan Kelurahan Rawa Makmur. Diperkirakan sumber pengairan dan kondisi persawahan mempengaruhi kelimpahan keong mas dalam suatu ekosistem.

\section{KESIMPULAN}

Pola distribusi keong mas (Pomacea canaliculata L.) pada stasiun pengamatan Kelurahan Rawa Makmur, Semarang, dan
Bukit Besar yaitu teratur $(\mathrm{Id}<1)$ sedangkan pada satu stasiun pengamatan Kelurahan Kandang Limun tidak ditemukan adanya keong mas. Kepadatan keong mas berkisar antara 3,52-5,78 ekor $/ \mathrm{m}^{2}$ dengan frekuensi kehadiran $100 \%$ kecuali pada stasiun pengamatan Kelurahan Kandang Limun. Kemudian kelimpahan keong mas berkisar antara 3,52-5,78 ekor $/ \mathrm{m}^{2}$ dengan kelimpahan tertinggi berada pada stasiun pengamatan Kelurahan Rawa Makmur.

\section{DAFTAR PUSTAKA}

Bakus, G. J. 1990. Quantitative ecology and marine biology. Department of Biological Science University of Southern California. Los Angeles. C. A. 90089-0371. A-A. Balkeman/Roterdam : 164 pp.

Brower, J.E. and J.H. Zar. 1990. Field and laboratory methods for general ecology. W. M. Brown Company Publ. Dubuque Lowa, $237 \mathrm{p}$.

Budiyono, S. 2006. Teknik mengendalikan keong mas pada tanaman padi. Jurnal Ilmu-ilmu Pertanian. 2(2): 128-133

Elfazuri. 1993. Ekologi Moluska zona intertidal di pantai tanjung rusa membalong belitung dan sumbangannya pada pengajaran biologi di Sekolah menengah atas. Sarjana Biologi FKIP UNSRI. Hal 33-37.

Estebenet dan Cazzaniga. 1992. Growth and demography of Pomacea canaliculata. (Gastropoda: Ampullaridae) under laboratory conditions. Malacological. Review. 25 (2): 1-12.

Halimah dan Ismail. 1989. Penelitian pendahuluan budidaya siput murbai. Jawa Barat: Bulletin Penelitian Perikanan darat. 38-43. 
Hendarsih, S dan Kurniawati, N. 2009. Keong mas dari hewan peliharaan menjadi hama utama padi sawah. Balai Besar Penelitian Tanaman Padi. Subang. http://www.litbang.depta.go.id/special/ padi/bbpadi_2009_itp_14.pdf diakses pada 17 Februari 2017.

[IRRI] International Rice Research Institute. 2003. Panduan Sistem Karakterisasi dan Evaluasi Tanaman Padi. Silitonga TS et al., penerjemah; Badan Penelitian dan Pengembangan Pertanian Komisi Nasional Plasma Nutfah. Bogor. 58 hlm. Terjemahan dari : Standard Evaluation System (SES) for Rice 4th edition, July 1996.

Martawidjaya, E.I., Martanto, E., dan Tinaprila, N. 2008. Panduan lengkap beternak itik secara intensif. Jakarta: Agromedia Pustaka.

Marwoto, R.M., N.R. Isnaningsih, N. Mujiono, Heryanto, Alfiah dan Riena. 2011. Keong air tawar pulau jawa (Moluska, Gastropoda). Lembaga Ilmu Pengetahuan Indonesia. Cibinong, 16 hlm.

Michael, P. 1984. Metode ekologi untuk penyelidikan ladang dan labotorium. Terjemahan oleh Yanti R. Koestoer. UI-Press. Jakarta.

Noviana, Y., 2012. Karakteristik kimia dan mikrobiologi silase keong mas (Pomacea canaliculata) dengan penambahan asam format dan bakteri asam laktat 3b104. Jurnal Fishtech. 1 (1) : $55-68$.

Nuhidayati. 1993. Studi Biologi Siput Murbai di Sumatra Selatan dan Sumbangannya pada Pengajaran Biologi di Sekolah Menengah Atas. Sarjana Biologi FKIP UNSRI. Hal 39.

Nurmufidah. 2015. Penambahan Keong Mas Pomacea Canaliculata L pada ransum ayam petelur dalam peningkatan kandungan omega 3 pada telur. Jurusan Biologi, Fakultas Matematika dan Ilmu Pengetahuan Alam, Universitas Hasanuddin, Makassar.

Nursalam. 2008. Konsep dan penerapan metodologi penelitian ilmu keperawatan. Jakarta: Salemba Medika.

Pagala. 2010. Pemberian keong mas (Pomacea sp) dalam pakan terhadap penampilan itik bali dan itik tegal. Staf Pengajar Pada Jurusan Peternakan Fakultas Pertanian Universitas Haluoleo. Kendari.

Permendagri No. 66, 2011. Kabupaten Kota Bengkulu.

http://www.kemendagri.go.id/pages/pr ofil-

daerah/kabupaten/id/17/name/bengkulu /detail/1771/kota-bengkulu diakses pada 20 November 2017.

Portal Berita Info Publik. 2016. Hama Keong Mas Resahkan Petani Tanjung Agung Kota Bengkulu. http://infopublik.id/read/145874/hamakeong-mas-resahkan-petani-tanjungagung-kota-bengkulu.html diakses pada 16 Februari 2017.

Riyanto. 2012. Pola Distribusi Populasi Keong Mas (Pomacea canaliculata L.) di Kecamatan Belitang OKU. Majalah Sriwijaya. Vol 31, Nomor 1 April 2004, Hal 70-75.

Rozakiah., Yolanda, R., dan Purnama, A.A. 2014. Kepadatan dan Distribusi Keong Mas (Pomacea canaliculata L.) di Saluran Irigasi Bendungan Batang Samo Desa Suka Maju Kabupaten Rokan Hulu. Pendidikan Biologi. FKIP. Universitas Pengaraian.

Setiono, D. 1999. Keberadaan Taman Nasional Baluran Terancam Acacia Nilotica (Akasia Duri). Jurnal Nasional Taman Baluran. 5 No 14, 1999. Hal 45-58 
Sihombing. 1999. Satwa Harapan I (Pengantar Ilmu dan Teknologi Budidaya). Bogor: Cetakan I Pustaka Wirausaha Muda.

Sugiyono. 2015. Metode penelitian tindakan komprehensif. Alfabeta: bandung

Suin, N.M. 1999. Metoda Ekologi. Direktorat Jenderal Pendidikan Tinggi Departemen Pendidikan dan Kebudayaan. Jakarta.

Sulistiono. 2007. Pengelolaan keong mas (Pomacea canaliculata). Prosiding. Konferensi Sains Kelautan dan
Perikanan Indonesia I. Kampus FPIK, IPB Dramaga, 17-18 Juli 2007: 124136.

Susanto. 1993. Siput Murbei. Kanisius. Jakarta..

Widiastuti, L. R., dkk. 2015. Struktur Populasi Dan Analisis Parasitologi Keong Mas (Pomacea canaliculata Lamarck 1819) Di Desa Jabungan, Semarang. Universitas Diponegoro: Semarang. 